\title{
Methane removal using materials from biofilters at composting plants
}

\author{
Loại bỏ khí Mê-tan bằng cách sử dụng vật liệu trong các bể lọc khí sinh học ở các cơ sở sản \\ xuất phân vi sinh
}

NGUYEN Thanh Phong ${ }^{*}$; Carsten CUHLS ${ }^{2}$

${ }^{1}$ Faculty of Science and Technology, Hoa Sen University, 8 Nguyen Van Trang, District 1, HCM city, Vietnam; ${ }^{2}$ Ingenieurgesellschaft für Wissenstransfer, Gewitra mbH, Im Moore 45, 30167 Hannover, Germany

\begin{abstract}
Methane $\left(\mathrm{CH}_{4}\right)$ source of Greenhouse Gases should be considered; $\mathrm{CH}_{4}$ is formed by composting under anaerobic conditions. Using microbial Methane oxidation is a solution with low cost and effective. In this study, 27 bio-filters and 18 laboratory-scale bioreactors were used to investigate the potential for $\mathrm{CH}_{4}$ removal in biogas. The $\mathrm{CH}_{4}$, Dinitrogen monoxide $\left(\mathrm{N}_{2} \mathrm{O}\right)$ and Carbon dioxide $\left(\mathrm{CO}_{2}\right)$ concentrations at the inlet and outlet of the air purifier were measured by gas chromatography. The results showed that the $\mathrm{CH}_{4}$ concentration decreased in experiments while the $\mathrm{CO}_{2}$ and $\mathrm{N}_{2} \mathrm{O}$ content increased in all experiments. An experiment was conducted with $1 \mathrm{~kg}$ of biofilter material with the input of 800 ppm $\mathrm{CH}_{4}$ contained in a 5 -liter flask for 49 hours containing. The results also showed that the $\mathrm{CH}_{4}$ concentration decreased by $71 \%$ after 20 hours and $\mathrm{N}_{2} \mathrm{O}$ was formed in the reactor.
\end{abstract}

\begin{abstract}
Mê-tan $\left(\mathrm{CH}_{4}\right)$ là nguồn khi gây nên hiệu ứng nhà kính cần được quan tâm, khí $\mathrm{CH}_{4}$ được sinh ra trong quá trình ủ vi sinh trong điều kiện kị khí. Một giải pháp với chi phí thấp là sử dụng vi sinh vật oxy hóa khí $\mathrm{CH}_{4}$ cố định trên giá thể là vật liệu sử dụng trong thiết bị lọc sinh học. Trong nghiên cứu này, 27 thiết bị lọc sinh học trên thực tế và 19 bình lọc tại phòng thí nghiệm đã được sử dụng nhằm mục đích khảo sát khả năng loại bỏ $\mathrm{CH}_{4}$ có trong khí sinh học. Nồng độ khí $\mathrm{CH}_{4}, \mathrm{~N}_{2} \mathrm{O}$ và $\mathrm{CO}_{2}$ ở đầu vào và đầu ra bể lọc khí được đo đạc bằng phương pháp sắc ký khí. Kết quả cho thấy nồng độ khi $\mathrm{CH}_{4}$ giảm sau khi qua hệ thống lọc sinh học ở một số bình, trong khi nồng độ khi $\mathrm{CO}_{2}$ và $\mathrm{N}_{2} \mathrm{O}$ lại tăng lên ở tất cả các bình. Khi khảo sát khả năng oxi hóa $\mathrm{CH}_{4}$ ở nồng độ 800 ppm của $1 \mathrm{~kg}$ vật liệu thiết bị lọc sinh học chứa trong bình phản ứng thể tích $5 \mathrm{~L}$ với thời gian 49 giờ. Kết quả cho thấy nồng nồng độ $\mathrm{CH}_{4}$ giảm $71 \%$ sau 20 giờ. Tuy nhiên, $\mathrm{N}_{2} \mathrm{O}$ đã được ghi nhận có hình thành trong bình phản ứng đó.
\end{abstract}

Keywords: greenhouse gas, emissions, composting, windrows, organic waste, methane, biofilter

\section{Introduction}

Methane $\left(\mathrm{CH}_{4}\right)$ and Dinitrogen monoxide $\left(\mathrm{N}_{2} \mathrm{O}\right)$ are considered to be strong Greenhouse Gases (GHGs), whereas $\mathrm{NH}_{3}$ is identified as an odour component and an indirect GHG. According to the Intergovernmental Panel on Climate Change (henceforth IPCC) Report in 2007, the Global Warming Potential (GWP) of $\mathrm{CH}_{4}$ and $\mathrm{N}_{2} \mathrm{O}$ in 100 years are respectively 25 and 298 times higher than that of $\mathrm{CO}_{2} \cdot \mathrm{CH}_{4}$ emissions from livestock account for $37 \%$ of the total emissions of $\mathrm{CH}_{4}$ in global, mainly for ruminants in digestion. In addition, landfill gas collection has been established to generate electricity and heat in many countries. The $\mathrm{CH}_{4}$ emitted from landfills is one of the major sources accounting for approximately $30 \%$ of total $\mathrm{CH}_{4}$ emissions (Kára et al., 2010). In other cases, flares are operated to burn $\mathrm{CH}_{4}$ and other organic trace compounds contained in the landfill gas before releasing to the atmosphere. However, these processes cannot be applied in cases of low $\mathrm{CH}_{4}$ concentration. Up to now, the mitigation of emissions with low $\mathrm{CH}_{4}$ concentrations often is neglected.

$\mathrm{CH}_{4}$ removal was observed with low gas flows and high concentrations in the soil or in biofilters (Bender \& Conrad, 1992). In a biofilter, an autochthonous methanotrophic biofilm can develop and use $\mathrm{CH}_{4}$ as a carbon source. However, the $\mathrm{CH}_{4}$ removal in biofilters varied from case to case due to different working conditions e.g. ambient temperature, humidity and nutrient content.

Most of the previous reports (Scheutz et al., 2009; Melse \& Van De Werf, 2005 and Bender \& Conrad, 1992) showed that a good $\mathrm{CH}_{4}$ oxidation rates of $20 \% \mathrm{CH}_{4}$ in the supply air and $2.5 \% \mathrm{CH}_{4}$ in the exhaust air. Biofilter has a high flow rate in a combination of low concentrations of $\mathrm{CH}_{4}$. Low $\mathrm{CH}_{4}$ concentrations range of below $0.07 \% \mathrm{CH}_{4}$ (700 ppm $460 \mathrm{mg} \mathrm{CH}_{4} / \mathrm{m}^{3}$ ) in combination with a high exhaust air volume flow in the range of $20,000-50,000 \mathrm{~m}^{3} / \mathrm{h}$. This results 
in a biofilter had a load of about $100 \mathrm{~m}^{3} / \mathrm{m}^{3}$.h. The efficiencies of $\mathrm{CH}_{4}$ reduction range from $0 \%-20 \%$ (Scheutz et al., 2009). In addition, Melse and Van De Werf (2005) reported a $\mathrm{CH}_{4}$ reduction of $80 \%$ in the biofilter with a load of 0.75 $\mathrm{m}^{3} / \mathrm{m}^{3} \cdot h$.

$\mathrm{CH}_{4}$ oxidation is therefore considered as an important method to $\mathrm{CH}_{4}$ emissions reduction. At present, only a few scientific publications on biological waste air treatment are available. Studies related to test the $\mathrm{CH}_{4}$ removal capacity of a new material have not yet been done. Looking into the real conditions of the biofilter, among different microorganism, $\mathrm{CH}_{4}$ oxidation bacteria needs to be found. Then, they will be enriched populations, which are added to the biofilter or bioscrubber on demand.

The aim of this work was to investigate $\mathrm{CH}_{4}$ removal in different biofilters and to develop a new method to find materials for $\mathrm{CH}_{4}$ oxidation.

\section{Materials and methods}

\subsection{Screening of biofilters}

Twenty-seven biofilters in composting plants in Germany were investigated in the study. The study was carried out from 2012 to 2014. An overview of a capsulated biofilter is shown in Figure 1. The gas before and after biofilter was analysed at each plant. At capsuled biofilters, the treated air left the biofilter in a chimney. Here the gases were measured. At the open biofilter of $16 \mathrm{~m}^{2}(4 \times 4 \mathrm{~m})$ was covered by a thin foil. Concentrations of the treated gases were measured under the foil.

Exhaust gases were sampled manually by evacuated headspace vials and subsequently analysed for $\mathrm{CH}_{4}, \mathrm{CO}_{2}$ and $\mathrm{N}_{2} \mathrm{O}$ by gas chromatography (ECD/FID, SRI 8610C, USA) in the laboratory in Bonn University, Germany. It was assumed that the volumes of treated and untreated air were the same.

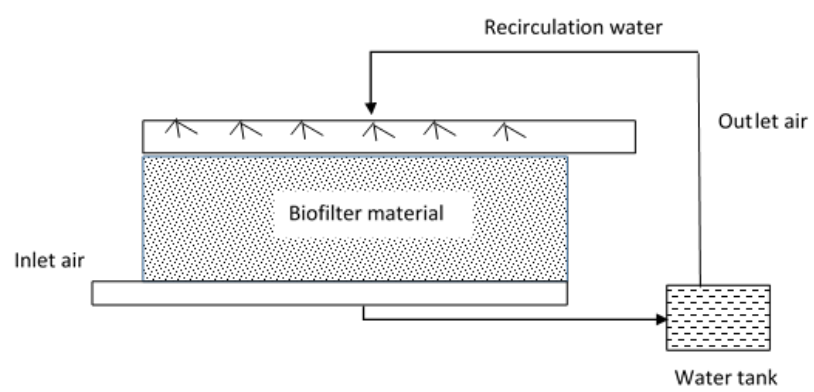

Figure 1. Schematic of a capsulated biofilter

\subsection{Experimental setup}

After screening of 27 biofilters, solid samples of the biofilters' from the most $\mathrm{CH}_{4}$ reduction was taken for laboratory experiments. The experiments were carried out in 18 batch reactors (5L) (Figure 2). Each batch reactor contained $1 \mathrm{~kg}$ biofilter's material at the outset of the experi- ment (Figure 3). It was assumed that methanotrophic bacteria was available on the material. $\mathrm{CH}_{4}$ (800 ppm) was mixed with air, humidified and introduced in the $5 \mathrm{~L}$ reactor. The mixing was pumped into reactors for 5 minutes to push out the existing air in the reactor. After pumping, the reactor was closed and no more Oxygen $\left(\mathrm{O}_{2}\right)$ was supplied. The air in the reactor is assumed to contain $\sim 20 \% \mathrm{O}_{2}$ together with the $800 \mathrm{ppm} \mathrm{CH}_{4}$. Samplings of incubated gases were taken to measure the concentrations of $\mathrm{CH}_{4}$ and $\mathrm{O}_{2}$.

The gases in the reactor were sampled at intervals of 1,2 , $19,22,24,26$ and 49 hours, and analysed for $\mathrm{CH}_{4}, \mathrm{CO}_{2}$ and $\mathrm{N}_{2} \mathrm{O}$ in the laboratory by GC-FID/ECD.

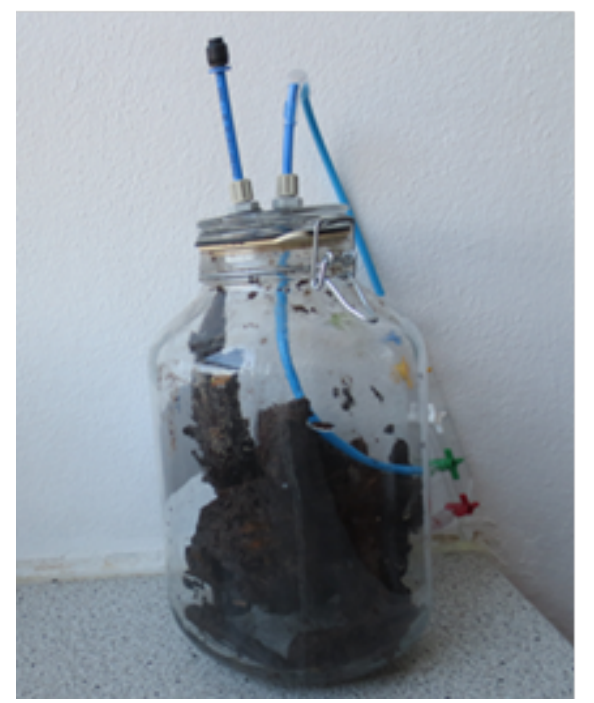

Figure 2. Test kit for determination of $\mathrm{CH}_{4}$ removal capacity

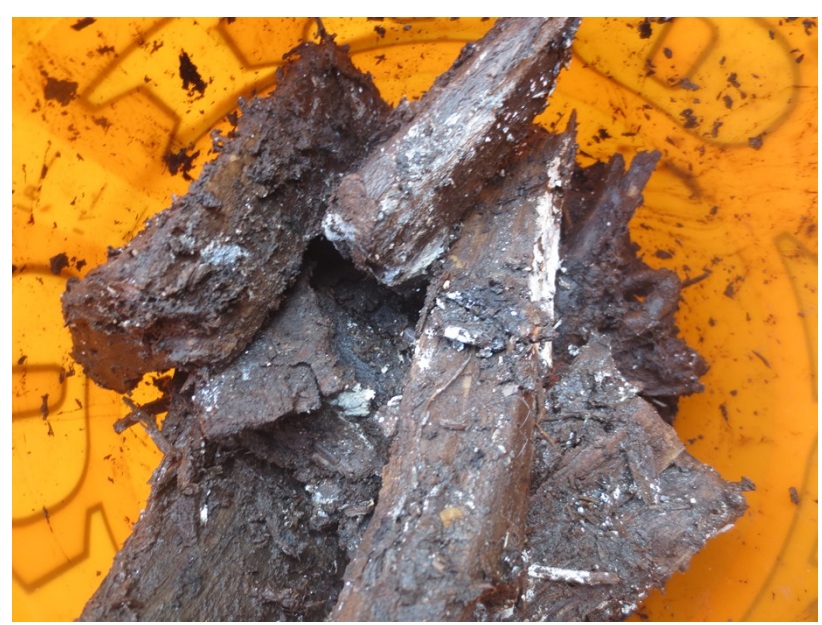

Figure 3. Material of biofilter for the testing of $\mathrm{CH}_{4}$ removal capacity

The removal performance was determined by mass balance according to the following equation:

$$
\mathrm{CH}_{4} \mathrm{ox} \_i=\frac{\left(\text { flux }_{i_{n}}-\text { flux }_{\text {out }}\right)}{\text { flux }_{\text {in }}} \times 100
$$

With

$\mathrm{CH}_{4} \mathrm{Ox} i$ : At the time $i$ oxidized portion of inlet flow [\%]

Flux $_{\text {in }}: \mathrm{CH}_{4}$ concentration flow into the reactor at time $i$ ( $i=$ 1, 2, 19, 22, 24, 26 and 49 hours) 
Flux out: $\mathrm{CH}_{4}$ concentration flow out the reactor at time $i$ ( $i=$ $1,2,19,22,24,26$ and 49 hours)

\section{Results and discussion}

\section{1 $\mathrm{CH}_{4}$ removal from biofilters at composting plants}

The inlet concentration of $\mathrm{CH}_{4}$ and $\mathrm{CH}_{4}$ reduction of biofilters were shown in Figure $4 . \mathrm{CH}_{4}$ was reduced and produced in the biofilters. The removal efficiency ranged from production of $-260 \%$ to reduction of $80 \%$ for $\mathrm{CH}_{4}$. The mean concentration of $\mathrm{CH}_{4}$ before biofilter was (106 \pm 73 ) ppm. The average $\mathrm{CH}_{4}$ removal efficiency was $25 \%$ at 13 biofilters. With regard to other literature, $\mathrm{CH}_{4}$ was reduced by $15 \%$ (Amlinger et al., 2008). As waste gas permeates the biofilter layer, $\mathrm{CH}_{4}$ is oxidized to $\mathrm{CO}_{2}$ and $\mathrm{H}_{2} \mathrm{O}$ by methanotrophic bacteria present in the biofilter's material. The effect on the production of $\mathrm{CH}_{4}$ emissions in the biofilter may be explained by anaerobic degradation of organic substances in the biofilter (Nguyen \& Cuhls, 2016). However, it is not yet well understood.

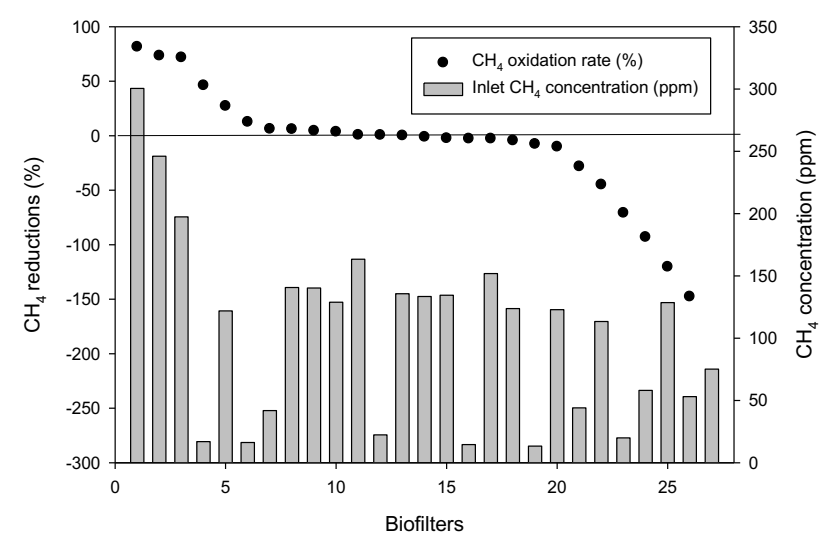

Figure 4. Inlet $\mathrm{CH}_{4}$ concentrations and removal efficiencies of $\mathrm{CH}_{4}$ at the studies biofilters

Table 1. Comparison of removal efficiency of biofilters: this study and data from literature (Scheutz et al., 2009)

\begin{tabular}{lcc} 
Reference & $\begin{array}{c}\mathrm{CH}_{4} \text { removal } \\
\text { (\%) }\end{array}$ & $\begin{array}{c}\mathrm{CH}_{4} \text { removal rate } \\
\max \left(\mathrm{g} / \mathrm{m}^{2} \text {.day) }\right.\end{array}$ \\
\hline This study & 7 to 27 & $5-56$ \\
Amlinger et al., 2008 & 15 & - \\
Trimborn, et al., 2003 & up to 26 & - \\
Du Plessis et al., 2003 & - & 87 \\
Wilshusen et al., 2004 & - & $96-276$ \\
Streese \& Stegmann, & - & 341 \\
2003 & & \\
Melse \& Van De Werf, & - & 377 \\
2005 & & 435 \\
Park et al., 2005 & - & 586 \\
Sly et al., 1993 & - & 592 \\
Haubrichs \& Widmann, & - & \\
2006 & & \\
Note: "-“ means data was not available &
\end{tabular}

The reductions of $\mathrm{CH}_{4}$ were lower than in previous studies (Table 1). Melse and Van De Werf (2005) reported the $\mathrm{CH}_{4}$ reduction of $80 \%$ in a biofilter with the load of 0.75 $\mathrm{m}^{3} / \mathrm{m}^{3}$.h. However, this loading factor is 130 times lower than in practice. Previous studies illustrated that the process-controlling factors of the $\mathrm{CH}_{4}$ oxidation in low-concentrations are the $\mathrm{O}_{2}$ availability, storage density and gas permeability as well as the volume flow of the gas to be treated (Bender \& Conrad, 1992: Benstead \& King 1997 and Dunfield et al., 1999). In fact, the low $\mathrm{CH}_{4}$ removal efficiency in practice could be explained by exposure time due to a short duration of the waste air treatment in biofilters.

\subsection{Methane oxidation reaction}

\subsubsection{The value of $\mathrm{pH}$}

The $\mathrm{pH}$ of biofilter's material was from neutral to a light alkaline (ranged from 7.16 to 7.82). The $\mathrm{pH}$ values were suitable for methanotrophic activities. The $\mathrm{CH}_{4}$ removal process was observed in a broad $\mathrm{pH}$ range, from $\mathrm{pH}<4$ in a sand soil to $\mathrm{pH}>9$ in a bog soil. The optimal pH for methanotrophs growth is between 6 and 8 (Cao \& Staszewska, 2011).

\subsubsection{Methane removal and carbon dioxide generation}

$\mathrm{CH}_{4}$ removal and $\mathrm{CO}_{2}$ generation were investigated for the biofilter's materials. The observed decrease in $\mathrm{CH}_{4}$ concentration in Figure 5 and 6 can be explained by oxidation since $\mathrm{O}_{2}$ was available and $\mathrm{CO}_{2}$ was increased. After an incubation for $49 \mathrm{~h}$ at $25^{\circ} \mathrm{C}, 99 \%$ of $\mathrm{CH}_{4}$ was consumed. The $\mathrm{CH}_{4}$ removal rate increased when the $\mathrm{O}_{2}$ concentrations increased from $2.5 \%$ to $15 \%$ (Cao \& Staszewska, 2011).

By comparison, the $\mathrm{CH}_{4}$ concentration in the reactor was 200 ppm after 20 hours (500 ppm reduction); whereas, the $\mathrm{CO}_{2}$ concentration was 3000 ppm (2500 ppm generation). This could be explained by aerobic decomposition of material in the reactor due to the availability of $\mathrm{O}_{2}$. Maximum $\mathrm{CH}_{4}$ consumption and maximum $\mathrm{CO}_{2}$ generation were observed at the first phase of incubation. Previous studies have shown that the rate of $\mathrm{CH}_{4}$ removal grows with the increase of $\mathrm{CH}_{4}$ concentration. The increase of $\mathrm{CH}_{4}$ concentrations from 2 to $16 \%$ leaded to 1.1 - 2.5 folds increase of the methanotrophic activity (Pawłowska \& Stępniewski, 2004). Another author found that a value (2.3-folds) in the methanotrophic activity increase was observed, where the measured $\mathrm{CH}_{4}$ concentration varied from 25 to 200 ppm (Whalen \& Reeburgh, 1996). 


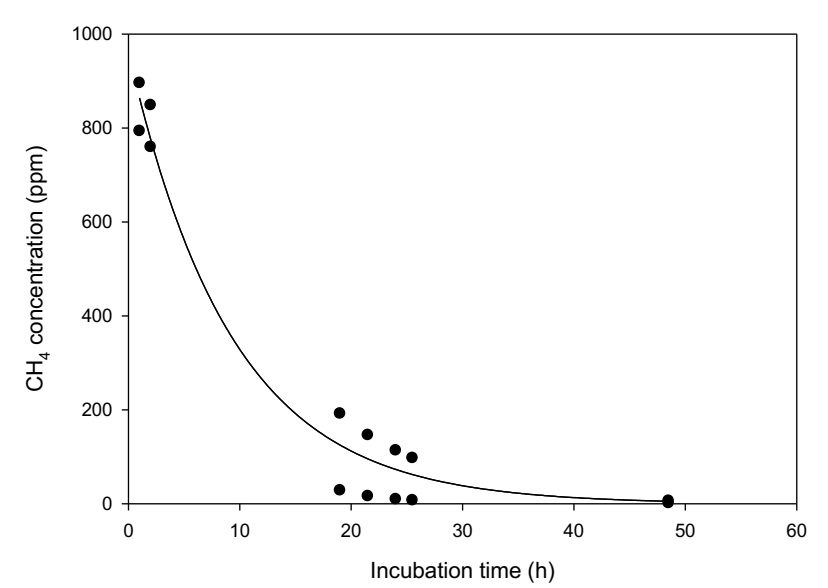

Figure 5. $\mathrm{CH}_{4}$ concentrations in the reactors during incubation time

$\mathrm{CO}_{2}$ concentration was increased steadily (Figure 6). $\mathrm{CO}_{2}$ generation was increased 15 times after 49 hours of incubation (from 3,400 ppm to 57,000 ppm). Although the amounts of $\mathrm{CH}_{4}$ removal by 3 replications were similar and decreased slightly after 20 hours' incubation, $\mathrm{CO}_{2}$ generation increased sharply. $\mathrm{O}_{2}$ is a significant factor influencing the $\mathrm{CH}_{4}$ oxidation process (Cao \& Staszewska, 2011).

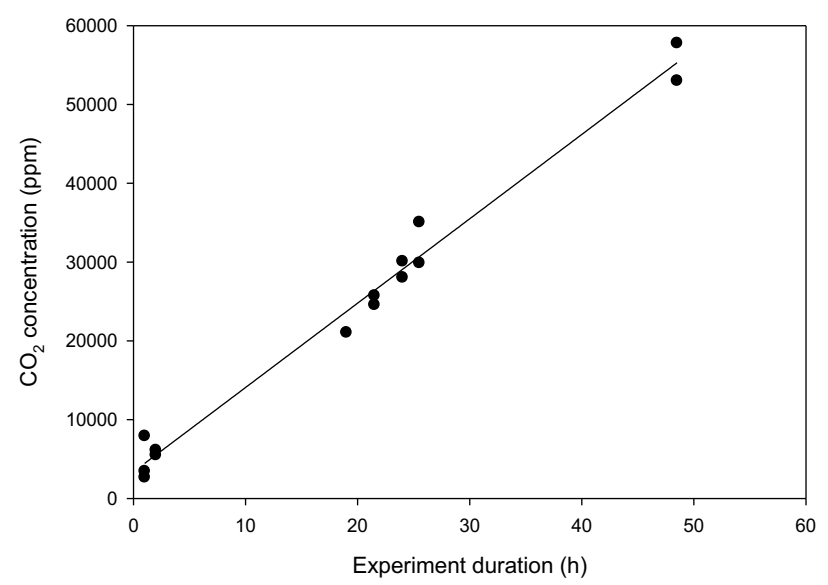

Figure 6. $\mathrm{CO}_{2}$ concentrations in the reactors during incubation time

\subsubsection{Nitrous oxide formation}

$\mathrm{N}_{2} \mathrm{O}$ generations were low at the start of the experiment and increased steadily to a maximum rate (Figure 7 ). The increase in $\mathrm{N}_{2} \mathrm{O}$ concentrations during the experiment is attributed to the nitrification process.

The formation of $\mathrm{N}_{2} \mathrm{O}$ during the further duration of the experiment indicates that some $\mathrm{N}_{2} \mathrm{O}$ production occurred in the biofilter material. The increase of $\mathrm{N}_{2} \mathrm{O}$ may be explained by the fact that $\mathrm{N}$ is converted to $\mathrm{N}_{2} \mathrm{O}$ by nitrification due to continuous aerobic conditions in the biofilters (Melse \& Van der Werf, 2005). According to previous studies, around one third $\mathrm{NH}_{3}$ that enters biofilters can be transformed and released as $\mathrm{N}_{2} \mathrm{O}$ (Trimborn, 2003). Similarly, Clemens and Cuhls (2003) reported that $26 \%$ of $\mathrm{NH}_{3}$ was transformed into $\mathrm{N}_{2} \mathrm{O}$ in biofilters.
The total cumulative $\mathrm{N}_{2} \mathrm{O}$ generation after $50 \mathrm{~h}$ incubation was $1.4 \mathrm{ppm}$ was much lower than the reduction of $\mathrm{CH}_{4}$ (823 ppm). After the end of the experiment, the contribution of $\mathrm{N}_{2} \mathrm{O}$ to the total $\mathrm{GHG}$ concentration in the outlet air is insignificant.

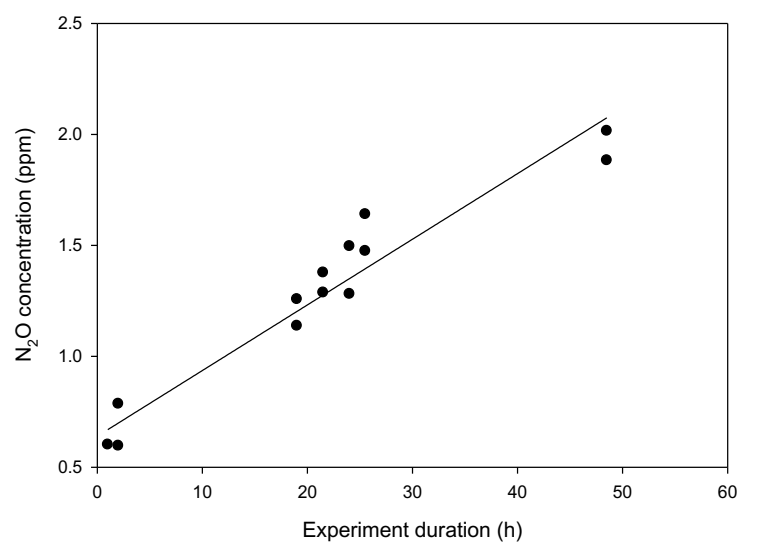

Figure 7. $\mathrm{N}_{2} \mathrm{O}$ concentrations in the reactors during incubation time

\section{Conclusions}

Biofilter has the capacity of $\mathrm{CH}_{4}$ removal and reduction. This is an attractive option for $\mathrm{CH}_{4}$ removal at low concentration in the organic waste treatment plants.

Results from experiments using biofilter's material showed that the material was an excellent property as a carrier for $\mathrm{CH}_{4}$ oxidation processes. Application of the microbial oxidation is a promising way to control the $\mathrm{CH}_{4}$ emission from organic waste treatment.

$\mathrm{CH}_{4}$ reduction rates in some biofilters were significantly lower than other. In biofilters, $\mathrm{CH}_{4}$ is either oxidized or produced due to the $\mathrm{O}_{2}$ availability. The $\mathrm{CH}_{4}$ oxidation rate was lower in some part of biofilters because of the anaerobic condition. Therefore, the designing the biofilters correspondingly should effectively promote the microbial $\mathrm{CH}_{4}$ removal of exhausted gas.

Further study is needed to understand and explain the $\mathrm{CH}_{4}$ formation and removal in the biofilter in order to optimize the $\mathrm{CH}_{4}$ and $\mathrm{N}_{2} \mathrm{O}$ reduction processes. More studies with the continues reactor should be carried out because GHG emission of $\mathrm{N}_{2} \mathrm{O}$ in the outlet air of the batch reactor was 3 times higher than the inlet gases. If it is the same tendency in the continuous reactor, it will be concerned more when the concentration of $\mathrm{CH}_{4}(\mathrm{GPW}=25)$ decreases 15 times when that of $\mathrm{N}_{2} \mathrm{O}(\mathrm{GPW}=298)$ increases three times in biofilter.

\section{References}

[1] Amlinger, F., Peyr, S. and Cuhls, C. 2008. Greenhouse gas emissions from composting and mechanical biological treatment. Waste Management and Research, 26, 47-60. 
[2] Bender, M. and Conrad, R. 1995. Effect of CH4 Concentrations and Soil Conditions on the Induction of $\mathrm{CH} 4$ Oxidation Activity. Soil Biol. Biochem. 27: 15171527.

[3] Bender, M. \& Conrad, R. 1992. Kinetics of CH4 oxidation in oxic soils exposed to ambient air or high $\mathrm{CH} 4$ mixing ratios. FEMS Microbiology Ecology 101: 261270.

[4] Benstead, J. \& King, G.M. 1997. Response of methanotrophic activity in forest soil to Methane availability. FEMS Microbiology Ecology 23: 333-340.

[5] Cao, Y. and Staszewska, E. 2011. Methane Emission Mitigation from Landfill by Microbial Oxidation in Landfill Cover, International Conference on Environmental and Agriculture Engineering, IPCBEE vol.15, IACSIT Press, Singapore.

[6] Clemens, J. and Cuhls, C. 2003. Greenhouse gas emissions from mechanical and biological waste treatment of municipal waste. Environmental Technology, 24: 745-754.

[7] Du Plessis, C.A., Strauss, J.M., Sebapalo, E.M.T. \& Riedel, K.-H.J. 2003. Empirical model for Methane oxidation using a composted pine bark biofilter. Fuel, 82: 1359-1365.

[8] Dunfield, P., Knowles, R., Dumont, R. \& Moore, T.R. 1993. Methane production and consumption in temperate and subartic peat soils: response to temperature and $\mathrm{pH}$. S Soil Biology and Biochemistry, 25: 321325.

[9] Haubrichs, R. \& Widmann, R. 2006. Evaluation of aerated biofilter systems for microbial Methane oxidation of poor landfill gas. Waste Management, 26: 408-416.

[10] IPCC. 2007. Climate change 2007- the Physical Science Basis. Contribution of Working Group I to the Fourth Assessment Report of the IPCC. Cambridge University Press, Cambridge, UK.

[11] Melse, R. W. and Van der Werf, A. W. 2005. Biofiltration for mitigation of Methane emission from animal husbandry. Environmental Science and Technology, 39: 5460-5468.
[12] Nguyen, T. P., Cuhls. C. 2016. The effect of turning frequency on methane generation during composting of anaerobicdigestion material, J. Viet. Env., 8(1): 50-55.

[13] Park, J.-R., Moon, S., Ahn, Y.M., Kim, J.Y. \& Nam, K. 2005. Determination of environmental factors influencing Methane oxidation in a sandy landfill cover soil. Environmental Technology, 26: 93-102.

[14] Kára, J., Janča, E., and Herák, D.2010. Exploitation of anaerobic fermentation of bio-degradable waste. Res. Agr. Eng. 56(1): 8-17.

[15] Scheutz, C., Bogner, J., De Visscher, A., Gebert, J., Hilger, H., Huber-Humer, M., Kjeldsen, P., Spokas, K. 2009. Microbial Methane oxidation processes and technologies for mitigation of landfill gas emissions. Waste Management \& Research, 27: 409455.

[16] Sly, L.I., Bryant, L.Y., Cox, J.M. \& Anderson, J.M. 1993. Development of a biofilter for the removal of Methane from coal mine ventilation atmospheres. Journal of Applied Microbiology and Biotechnology, 39: 400-404.

[17] Stępniewski, W., Pawłowska, M. and Rożej A. 2009. Microbial Oxidation of Methane in a Mineral-Based Aerated Biofilter - Model Studies. The International Conference on Soild Waste Management Technical, Environmental and Socio-economical Contexts Waste Safe, Khulna, Bangladesh. 55-64.

[18] Streese J. \& Stegman, R. 2003. Microbial oxidation of $\mathrm{CH} 4$ from old landfills in biofilters. Waste Management, 23: 573-580.

[19] Trimborn, M., Goldbach, H., Clemens, J., Cuhls, C. and Breeger, A., 2003. Reduction of greenhouse gases in the exhaust air of biofilters at biowaste treatment plants. In: Band 14 der Bonner Agrikulturchemischen Reihe, Abschlußbericht.

[20] Whalen, S.C., Reeburgh, W.S. and Sandbeck, K.A. 1990. Rapid Methane Oxidation in a Landfill Cover Soil. Appl Environ Microbiol. 56(11): 3405-3411.

[21] Wilshusen, J.H., Hettiaratchi, J.P.A., De Visscher, A. \& Saint-Fort, R. 2004. Methane oxidation and formation of EPS in compost: Effect of Oxygen concentration. Environmental Pollution, 129, 305-314. 